\title{
Techno-Economic Evaluation of Hybrid Energy Isolated Micro-Grids for Rural Areas in Four Zones of Egypt
}

\author{
Samir M. Dawoud \\ Department of Electrical Power and Machine Engineering, Faculty of Engineering, Tanta University, Tanta, Egypt \\ sameer_dawood@f-eng.tanta.edu.eg
}

\section{Abstract}

In this paper, Rural electrifications and optimum sizing of isolated hybrid micro-grids improve the quality of the life in rural areas by using the optimization technique. The hybrid isolated micro-grids consist of wind turbine (WT), solar voltaic (SPV) systems, storage unit batteries, and diesel generators as a backup to feed electric load demand requirements. A software homer optimization technique has been used to model isolated micro-grid performance during a time of one year, considering hourly variations in both the availability of renewable resources and variations in load demands. The optimum solution is obtained considering the minimization of the levelized costs of energy (LCOEs) over a project lifetime of 25 years. The simulations concentrated on the net present costs (NPCs), LCOEs, and a renewable fraction (RFs) of the given hybrid isolated micro-grids for all four zones. The gotten analyses show that SPV/wind/diesel/battery storage hybrid isolated micro-grids configuration is found as optimal solutions for $1.3 \$ / 1$ of diesel fuel consumption. It also showed a better performance in fuel consumption and gas greenhouse $\mathrm{CO} 2$ reduction. This paper studied the feasibility of different isolated micro-grid configurations comprising SPV, WT, and diesel in different areas of Egypt. Four rural isolated micro-grids have been randomly chosen for the four areas in Egypt with the intention that the obtained results of this study could be replaced in other rural locations of the selected areas with similar terrains. HOMER simulation was used to calculate the economic feasibility of the isolated micro-grids. The simulations focused on the LCOEs and RFs of the given hybrid component for all four regions. The analyses showed that SPV/wind/diesel/battery hybrid isolated micro-grids configuration is found as the best architecture for all rural areas. It also presented a good performance in fuel consumption and $\mathrm{CO} 2$ reduction.

\section{Keywords-Isolated micro-grids, Homer Optimization,}

\section{INTRODUCTION}

Nowadays the world energy request is increasing at a fast rate compared to the growth of the human population [1]. In the developing countries, it is expected that the largest increase will occur, where more people in these countries still do not have sufficient energy for people energy requirements [2]. The isolated system has been applied using diesel generators or more renewable energy resources, but because of the increasing development of WT, SPV sources, and diesel fuels have high costs and high environmental pollutions, these traditional systems are being modernized to combine more renewable energy technologies [3-4].

The design of hybrid micro-grids by optimization software techniques is driven by the requirements to overcome the convolution of decision making in the presence of large variability of renewable microgrids resources, variable energy load requirement profile, cost characteristics, and different performance of equipment. The hybrid microgrid evaluation has been described using optimization software tools, different performance schemes, and different techniques [5-6]. The methodology suggested a dynamic system to calculate the optimal operating strategy for a wind turbine with a diesel and battery storage system during one day [7]. In [8] the authors have used the optimum design of WT with diesel and battery storage system based on the structure of trade-offs shapes. So the economics of charging batteries storages with diesel power are shown in comparison

Received:20 Augest, 2020, Accepted:11 March, 2021

Rural electrifications, and Techno-economic evaluation

with alternative models. The authors in reference [9] suggest

a non-linear constrained system to obtain the optimum combinations of a model that contains hydro, SPV, wind turbine, diesel, and batteries storages using an iterative method. The best model is chosen from several combinations that are compared together. The optimum sizing scheme for an isolated grid with diesel is existing in [10-11]. The optimization technique is based on GA to choose the optimum size of WT, SPV rated power, battery storage nominal capacity, and inverter rating. The advantage of using renewables energies compared to a standalone diesel system is then measured. Though in both works, the diesel systems are high cost, and the resize is not recommended for an economic solution in Ref. [12]. The use of hybrid energy Systems in Egypt is considered the main way for future energy and can decrease the amounts of the emissions of gaseous resulted from fossil fuels [13]. In this reference, four different hybrid systems are discussed, and the comparisons were obtained to get a proper design for Hurghada city. From this literature review, it is clear that different sub-systems have been studied, different optimization methods have been used, and different time horizons considered. The main contribution of this article is to offer the integrated methodology of the sizing and planning of hybrid microgrids containing the main renewable sources, SPV and WT, batteries storages, and a backup diesel generator for four rural areas in Egypt. Four rural isolated micro-grids have been randomly chosen for the four areas in Egypt. The other thing of the article is planned as follows. Section II describes the problem definition and isolated micro-grid modeling. Section III is concerned with system descriptions and simulations model of the hybrid system. The gotten results 
being discussed in section IV. The conclusions showed in section $\mathrm{V}$.

\section{Problem Definition AND ISOlated MiCRO-GRIDS MODELING}

\section{A. Problem Definition}

Four isolated micro-grids are considered for the rural regions in Egypt that consist of WT energy, SPV, batteries storages, and diesel generators. The objective is to obtain the optimum scheme of isolated micro-grids that minimizes the LCOE while feeding load demands under uninterruptible conditions. Assuming the renewable resources variations, load profile, and general technical characteristics like rated power, initial cost, and efficiency. The No. of SPV, wind turbine, diesel generators, and storages batteries capacity have been evaluated, to allow continuous operation. Diesel engines and batteries have been used as a backup for renewables sources. Diesel generators are cheap and easy to use, but the fuel consumptions are high when working in temporary modes. Batteries storages are expensive and the No. of charge/discharge cycles change their lifespan. The resize and usage of the battery can be kept to a low value to minimize the total cost. The time of the project considered is one year with a time step of one hour. From the modeling, it is direct to consider a smaller time step discretization but that would significantly increase the No. of variables and constraints leading to a higher computational time.

\section{B. Isolated Micro-grids Modeling.}

The isolated micro-grids sources, particularly SPV and WT are characterized by their uncertainties in a time frame in addition to in magnitude. The best method to get around these uncertainties would be to couple them with other steady controllable energy supplies. Figure 1 displays the schematic diagram for the SPV/wind/diesel system connected to battery storage.

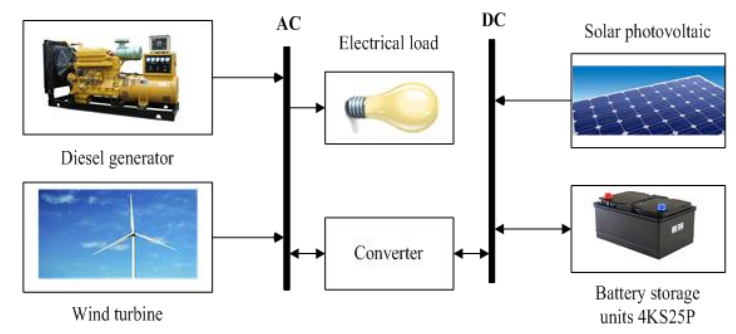

Fig. 1. Hybrid SPV/wind/diesel isolated micro-grids with battery storage.

\section{Wind energy subsystem}

The wind turbine's power output at a certain place depended on the value of wind speeds at hub height and the rated speed of the WT system. Wind speeds at hub height calculated by:

$v_{s}=v_{i}\left[\frac{h}{h_{i}}\right]^{x}$

Where $v_{s}$ and $v_{i}$ are the wind speeds at the heights $h$ and $h_{i}$ respectively. $\mathrm{x}$ is a power law and power output $\mathrm{P}_{\mathrm{WT}}$ $\left(\mathrm{kW} / \mathrm{m}^{2}\right)$ obtained from a wind turbine can be computed by[14]:

$$
P_{W T}(t)= \begin{cases}0, & V \leq V_{\text {in }}, V \geq V_{\text {cout }} \\ A V^{2}-B P_{r}, & V_{\text {in }} \leq V \leq V_{r} \\ P_{r}, & V_{r} \leq V \leq V_{\text {cout }}\end{cases}
$$

$A=\frac{P_{r}}{V_{r}^{3}-V_{i n}^{3}}$

$$
B=\frac{V_{i n}^{3}}{V_{r}^{3}-V_{i n}^{3}}
$$

$P_{e, w}=P_{W T} A_{W T} e f_{W T}$

Where $A, B$ are the wind power characteristic curve parameters, slightly different for different wind turbines; $P_{r}$ is the wind turbine rated power; $v_{i n}, v_{r}, v_{\text {cout }}$ are the cut-in, rated and cut-out wind speed and the values of these speeds is $2.5 \mathrm{~m} / \mathrm{s}, 12 \mathrm{~m} / \mathrm{s}, 24 \mathrm{~m} / \mathrm{s}$ with rotor diameter $13 \mathrm{~m}$ respectively. $\mathrm{A}_{\mathrm{WT}}$ is a total swept area of wind turbine and ef $f_{W T}$ is an efficiency of WT. The relationship curve between the output power and wind speed is shown in Figure 2.

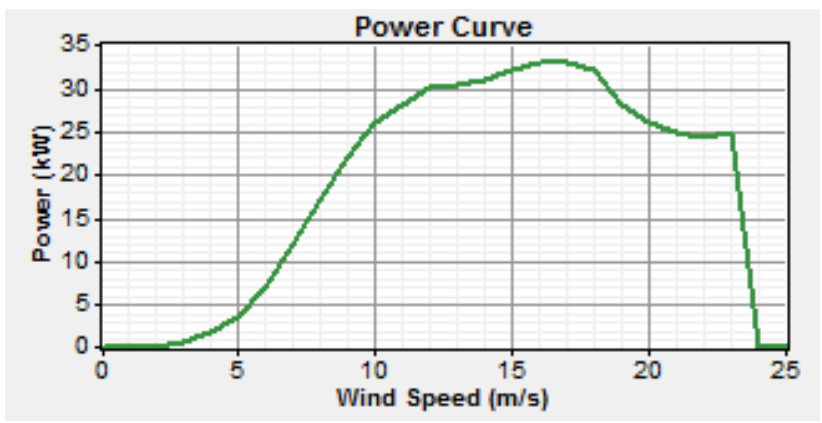

Fig. 2. wind turbine output power

\section{Photovoltaic energy subsystem [15]}

The current output of SPV panels is evaluated in Equation (6). The Cell photocurrent $\left(\mathrm{I}_{\mathrm{ph}}\right)$, Cell reverse saturation current $\left(\mathrm{I}_{\mathrm{rs}}\right)$, Cell saturation current $\mathrm{I}_{\mathrm{o}}$, varies with the cell temperature and the current output of SPV cell (I) are existing in the below equations.

$\mathrm{I}_{\mathrm{ph}}=\left[\mathrm{I}_{\mathrm{scr}}+\mathrm{K}_{\mathrm{i}}\left(\mathrm{T}_{\mathrm{m}}-298\right)\right]^{* \lambda / 1000}$

$\mathrm{I}_{\mathrm{rs}}=\mathrm{I}_{\mathrm{scr}} /\left[\exp \left(\frac{\mathrm{V}_{\mathrm{or}} q}{\mathbb{N}_{\mathrm{s}} \mathbb{K}_{\mathrm{i}} A_{\mathrm{i}} T_{\mathrm{m}}}\right)-1\right]$

$\mathrm{I}_{0}=\mathrm{I}_{\mathrm{rs}}\left[\frac{T_{\mathrm{m}}}{\mathrm{T}_{\mathrm{g}}}\right]^{3} \exp \left[\frac{\mathrm{q}^{*} \mathrm{E}_{\mathrm{gp}}}{A_{\mathrm{i}} \mathrm{K}_{\mathrm{i}}}\left\{\frac{1}{T_{r}}-\frac{1}{T_{m}}\right\}\right]$

$\mathrm{I}=\mathrm{N}_{\mathrm{p}} * \mathrm{I}_{\mathrm{ph}}-\mathrm{N}_{\mathrm{p}} * \mathrm{I}_{\mathrm{o}} *\left(\mathrm{e}^{\frac{\mathrm{q} *\left(\mathrm{~V}+\mathrm{V} * R_{s}\right)}{N_{s} K A_{\mathrm{i}} T_{\mathrm{m}}}}-1\right)-\frac{\left(\mathrm{V}+\mathrm{I}^{*} R_{s}\right)}{R_{V}}$

Where, $\mathrm{I}_{\mathrm{scr}}$ is SPV module short-circuit current at $25^{\circ} \mathrm{C}$, $\mathrm{K}_{\mathrm{i}}$ is a short-circuit current temperature coefficient at $\mathrm{I}_{\mathrm{SCr}}=$ $0.0017\left(\mathrm{~A} /{ }^{\circ} \mathrm{C}\right)$ and $1000 \mathrm{~W} / \mathrm{m}^{2}(\mathrm{~A}), \mathrm{T}_{\mathrm{r}}$ is the reference temperature $=298(\mathrm{~K}), \mathrm{T}_{\mathrm{m}}$ is module operating temperature $(\mathrm{K}), \lambda$ is SPV module illumination $\left(\mathrm{W} / \mathrm{m}^{2}\right)=1000 \mathrm{~W} / \mathrm{m}^{2}, \mathrm{q}$ is an electron charge $\left(1.6 \times 10^{-19}(\mathrm{C})\right), \mathrm{V}_{\mathrm{oc}}$ is SPV cell open- 
circuit voltage at $25^{\circ} \mathrm{C}$ and $1000 \mathrm{~W} / \mathrm{m}^{2}, \mathrm{~N}_{\mathrm{s}}$ is No. of the solar cells connected in a series, $\mathrm{N}_{\mathrm{p}}$ is No. of solar cells connected in a parallel, $A_{i}$ is ideality factor (1.6) and $E_{g o}$ is bandgap of silicon $(1.1 \mathrm{eV})$.

\section{Diesel generator}

Diesel generator works as a voltage-stability organizer through the system isolated operation. After there is a lack of solar output, the diesel engine raises its output to recompense the lack of power. The minimum operating ratio of diesel is taken as $25 \%$ of the generator power output. The fuel generator curve of the intercept coefficient is assumed as $0.014 \mathrm{~L} / \mathrm{hr} / \mathrm{kW}_{\text {rated. The fuel engine curve slope is }}$ supposed as $0.244 \mathrm{~L} / \mathrm{h} / \mathrm{kW}$ output.

\section{4. battery storage system}

The electric battery is an important part of any hybrid renewable energy system. The main disadvantages of employing a battery system are its cost and the know-how to choose the appropriate rating of it. A battery is an electrical device containing one or several electrochemical cells. It has two poles: positive pole is the anode and negative pole is the cathode and is the source of electrons when connected to an external device. The electrons allow the passage of ions through them in the sense that it is a chemical reaction and thus out of energy for the device, the current that comes out of the battery movement of ions within the battery.

\section{Economic analysis}

HOMER software compares the economics of the wide ranges of system configurations containing variable No. of renewable and unrenewable energy resources [16]. For equality constraint, such comparisons must explanation for both initial and operating costs for each energy resource. In this article, two parameters including LCOE and RFs were used to estimate the performance of hybrid systems.

\section{Levelized cost of energy( $L C O E)$}

HOMER combines the initial, replacement, fuel costs, and salvage values for each component to get the component's annualized cost. LCOE is an average cost per kilo Wh of the useful electric energy resulted from the hybrid system. To compute the LCOE, HOMER program divides the total annualized costs of producing electricity by total electrical energy production as given in the following equation:

$L C O E=C_{\text {antot }} /\left(E_{\text {prim }}\right)$

Where $C_{a n, t o t}$ is a total annualized cost, $E_{\text {prim }}$ is total amounts of electrical load that the hybrid system serves annually.

\section{Renewable fraction $(R F s)$}

RFs is the total amounts of power generated by the renewable energy resources compared to the total power generation from then entire hybrid energy systems [14]. RFs is usually wanted to be as high as possible because the electric loads are predictable to make the maximum usage of the renewable sources. The RFs is obtained from the following equation.
$\operatorname{RFs}(\%)=100\left(1-\frac{\sum P_{d s}}{\sum P_{\text {mom }}}\right)$

Where $\mathrm{P}_{\text {ren }}$ and $\mathrm{P}_{\text {dis }}$ are the power output of renewable energy and diesel output power respectively.

\section{SYSTEM DESCRIPTIONS AND SIMULATIONS MODEL FOR HYBRID MICRO-GRID}

\section{A. System Descriptions}

The load profile considered average energy consumption by the proposed area and it is $85 \mathrm{kWh} / \mathrm{d}$. Fig 3 shows the daily average load profile. Here, $11 \mathrm{~kW}$ is considered as peak load consumption. The scaled annual average $(\mathrm{kWh} / \mathrm{d})$ is assumed 85. Fig. 4 shows the monthly average load in the proposed region. The data of solar resources was gotten from the NASA website. Tables I and II show solar irradiation and the wind speed of the four towns of Egypt, respectively. Table III shows the locations of the four towns. The specific location of Hurghada-Egypt is at a location of $27^{\circ} 15^{\prime} \mathrm{N}$ latitude and $33^{\circ} 48^{\prime} \mathrm{E}$ longitude with annual average solar irradiation of $6.25 \mathrm{kWh} / \mathrm{m}^{2} / \mathrm{d}$ as displayed in Figure 5. The actual wind speeds are obtained for Hurghada and the scaled annual average speed is $7 \mathrm{~m} / \mathrm{s}$ as displayed in Figure 6 . Hurghada town has a wind speed rate between $5 \mathrm{~m} / \mathrm{s}$ and 9 $\mathrm{m} / \mathrm{s}$ and an average speed rate of $6.65 \mathrm{~m} / \mathrm{s}$. The high wind and low wind speeds of months of a year are detected in Sep. and Nov., respectively.

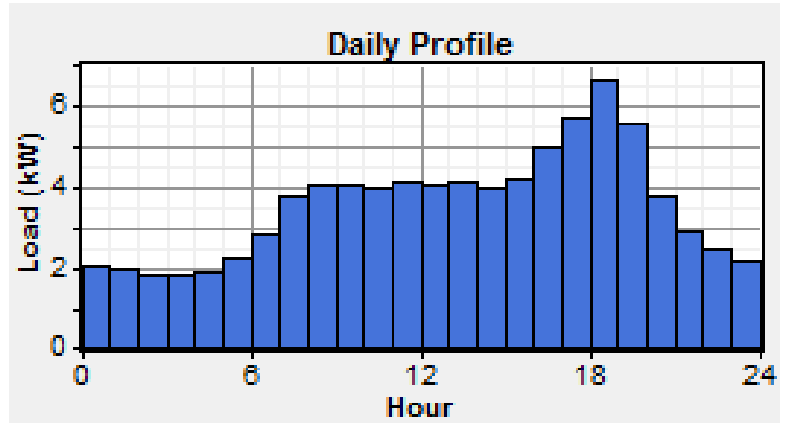

Fig. 3. Load profile (daily)

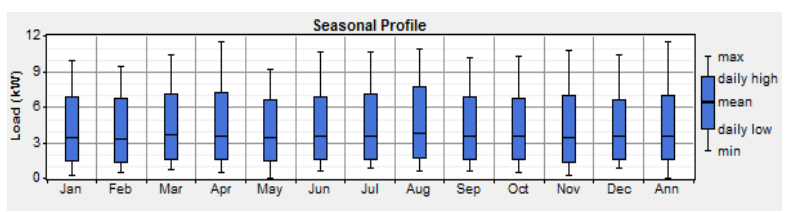

Fig. 4. Load for a complete year (monthly average) 


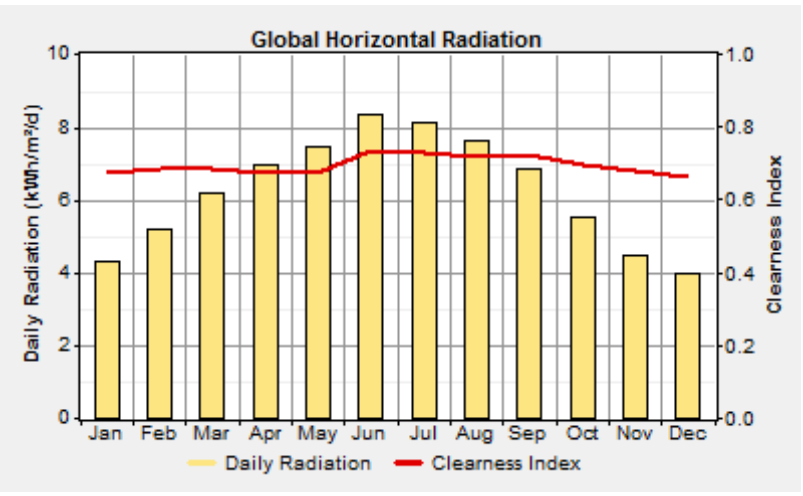

Fig. 5. Annual average solar irradiation of Hurghada.

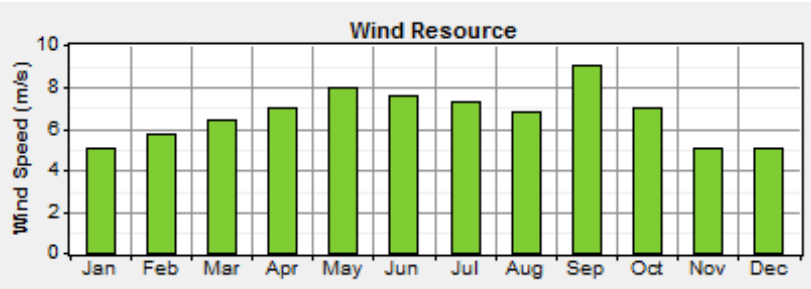

Fig. 6. The scaled annual average speed of Hurghada.

TABLE I. SOLAR RADIATION DATA OF THE FOUR TOWNS, $\left(\mathrm{KWH} / \mathrm{M}^{2} / \mathrm{DAY}\right)$

\begin{tabular}{|l|c|c|c|c|}
\hline & $\begin{array}{c}\text { Abu } \\
\text { Simbel }\end{array}$ & Hurghada & Matrouh & Aswan \\
\hline Jan. & 5.100 & 4.285 & 2.882 & 4.592 \\
\hline Feb. & 5.985 & 5.176 & 3.745 & 5.372 \\
\hline Mar. & 6.752 & 6.211 & 5.003 & 6.444 \\
\hline Apr. & 7.381 & 6.980 & 6.023 & 6.895 \\
\hline May & 7.281 & 7.468 & 6.904 & 7.353 \\
\hline Jun. & 7.640 & 8.324 & 7.690 & 7.927 \\
\hline Jul. & 7.225 & 8.116 & 7.506 & 7.604 \\
\hline Aug. & 6.931 & 7.617 & 7.008 & 7.055 \\
\hline Sep. & 6.558 & 6.861 & 5.883 & 6.582 \\
\hline Oct. & 5.974 & 5.522 & 4.319 & 5.666 \\
\hline Nov & 5.293 & 4.475 & 3.265 & 4.785 \\
\hline Dec. & 4.773 & 3.96 & 2.738 & 4.303 \\
\hline Average & 6.408 & 6.254 & 5.254 & 6.218 \\
\hline
\end{tabular}

TABLE II. WIND SPEED DATA OF THE FOUR TOWNS (M/S)

\begin{tabular}{|l|c|c|c|c|}
\hline & $\begin{array}{c}\text { Abu } \\
\text { Simbel }\end{array}$ & Hurghada & Matrouh & Aswan \\
\hline Jan. & 3.000 & 5.000 & 5.000 & 4.000 \\
\hline Feb. & 3.000 & 5.700 & 5.000 & 4.000 \\
\hline Mar. & 4.000 & 6.400 & 5.000 & 5.000 \\
\hline Apr. & 3.000 & 7.000 & 5.000 & 4.000 \\
\hline May & 4.000 & 8.000 & 4.000 & 4.000 \\
\hline Jun. & 4.000 & 7.600 & 4.000 & 4.000 \\
\hline Jul. & 4.000 & 7.300 & 4.000 & 4.000 \\
\hline Aug. & 4.000 & 6.800 & 4.000 & 4.000 \\
\hline Sep. & 4.000 & 9.000 & 4.000 & 4.000 \\
\hline Oct. & 4.000 & 7.000 & 3.000 & 4.000 \\
\hline Nov & 4.000 & 5.000 & 4.000 & 4.000 \\
\hline Dec. & 4.000 & 5.000 & 5.000 & 4.000 \\
\hline Average & 3.765 & 6.652 & 4.329 & 4.085 \\
\hline
\end{tabular}

TABLE III. SELECTED TOWNS OF THIS STUDY WITH THEIR LOCATIONS.

\begin{tabular}{|l|l|l|l|l|}
\hline & Abu & Hurghada & Matrouh & Aswan \\
\hline
\end{tabular}

\begin{tabular}{|l|c|l|l|l|}
\hline & Simbel & & & \\
\hline Latitude (N)/ & $21^{\circ} 18^{\prime} \mathrm{N}$ & $27^{\circ} 15^{\prime} \mathrm{N}$ & $31^{\circ} 19^{\prime} \mathrm{N}$ & $24^{\circ} 4^{\prime} \mathrm{N}$ \\
Longitude (E) & $34^{\circ} 4^{\prime} \mathrm{E}$ & $33^{\circ} 48^{\prime} \mathrm{E}$ & $27^{\circ} 9^{\prime} \mathrm{E}$ & $32^{\circ} 57^{\prime} \mathrm{E}$ \\
\hline
\end{tabular}

\section{B. Simulation Model of Hybrid System.}

Figure 7 shows off-grid hybrid systems design using HOMER which contains an SPV array, diesel generator, wind turbine, converter, load, and battery. Every source from the previous has details that can be put into a program to have an actual result. HOMER software discusses the principle of optimization so the cost should be an important part of the program. HOMER differentiates between the fuel costs of diesel and the costs of diesel generator equipment so the cost of fuel should be inserted. According to environmental protocols, there are penalties on emissions, HOMER uses these penalties and adds its cost to the cost of a project such that the Intercept coeff. ( $\mathrm{L} / \mathrm{hr} / \mathrm{kW}$ rated)equal 0.08 and Slope (L/hr/kW output) equal 0.25 . for the monocrystalline silicon solar panel. Its efficiency is about $19 \%$ and its lifetime about 25 years. It can withstand high temperature and It can withstand high pressure. We should notice that the initial installation cost of SPV arrays is assumed as $\$ 2000$ per $\mathrm{kW}$, and operation \&maintenance costs practically zero. The best choice will be the central converter because it is designed for navigational purposes, economical, and cheap more than other types. Notice that: the converter functions as both an inverter (converting DC to $\mathrm{AC}$ ) and rectifier (AC to DC). This will not affect the results of an analysis of a hybrid system that only requires an inverter. The specification of all components is presented in Table IV

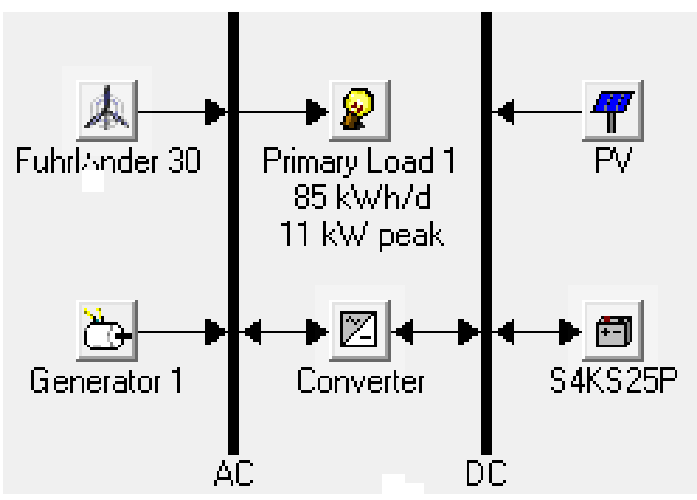

Fig. 7. Hybrid system schematic in HOMER.

TABLE IV. SPECIFICATIONS OF ISOLATED MICRO-GRID.

\begin{tabular}{|c|c|c|c|c|}
\hline & $\begin{array}{c}\text { Size } \\
(\mathbf{k W})\end{array}$ & $\begin{array}{c}\text { Capital } \\
\mathbf{( \$ )}\end{array}$ & $\begin{array}{c}\text { Replacement } \\
(\mathbf{\$})\end{array}$ & $\begin{array}{c}\text { O\&M } \\
\mathbf{( \$ / y )}\end{array}$ \\
\hline Diesel & 1.000 & 450 & 400 & 0.090 \\
\hline SPV & 1.000 & 2000 & 1800 & 0 \\
\hline WT & 30 & 27500 & 25000 & 100 \\
\hline Battery & 7.6 & 1250 & 1100 & 15 \\
\hline Converter & 1.000 & 700 & 650 & 15 \\
\hline
\end{tabular}

\section{RESULTS AND DISCUSSION}

The result includes numerical values which contain the capacity of Photovoltaic., Number of Batteries units, Capacity of Converter, the initial cost of a system, operating cost of the system, total NPCs, LCOE per year, Hours of 
operation for diesel, and No. of diesel fuel in liters. Table V and VI show isolated micro-grid architecture taking $\mathrm{kW}$ SPV array rating, wind turbine, diesel generators, the power converter, and the electrical production. The No. of storage batteries needed for energy battery is indicated under microgrid architecture. The conventional stand-alone diesel engine is currently employed in every rural area in Egypt and hence considered as the diesel simulation in this paper. It is selected to permit the comparisons to be made about total savings which can be get by including renewable resources in isolated microgrid designing (i.e comparing costs and the amount of emissions for diesel with the proposed hybrid SPV/wind/diesel configuration). SPV/wind/ diesel/battery configurations are adjudged an optimum best, for all the four rural areas, and hence comparing with the diesel system considering the LCOE, RFs, and amount of emissions for the diesel price ( $\$ 1.3 / \mathrm{L})$.

TABLE V. SYSTEM ARCHITECTURE FOR FOUR TOWNS

\begin{tabular}{|l|c|c|c|c|}
\hline & $\begin{array}{c}\text { Abu } \\
\text { Simbel }\end{array}$ & Hurghada & Matrouh & Aswan \\
\hline SPV (kW) & 4 & 4 & 4 & 4 \\
\hline Diesel (kW) & 5.5 & 5.5 & 5.5 & 5.5 \\
\hline WT (kW) & 30 & 30 & 30 & 30 \\
\hline $\begin{array}{l}\text { Converter } \\
\text { (kW) }\end{array}$ & 5 & 5 & 5 & 5 \\
\hline $\begin{array}{l}\text { No. of } \\
\text { batteries }\end{array}$ & 8 & 8 & 6 & 8 \\
\hline
\end{tabular}

TABLE VI. KWH/YR OF DIFFERENT TOWNS FOR DIFFERENT SOURCES

\begin{tabular}{|l|c|c|c|c|}
\hline & $\begin{array}{c}\text { Abu } \\
\text { Simbel }\end{array}$ & Hurghada & Matrouh & Aswan \\
\hline SPV & 10230 & 12600 & 10225 & 12183 \\
\hline Diesel & 1062 & 1000 & 1352 & 1105 \\
\hline WT & 110121 & 108722 & 109489 & 110103 \\
\hline
\end{tabular}

\section{A. Total LCOE Calculations.}

The LCOE of all the feasible isolated micro-grid configurations considered for implementation of a hybrid microgrid in certain areas is shown in Table VII for diesel prices of $\$ 1.3 / 1$. LCOE is evaluated for the whole model considering the expected life of 25 years. The system configuration includes a standalone diesel-only system, wind/diesel/battery, SPV/wind/battery, and SPV/wind/ diesel/battery. LCOE of SPV-wind-diesel-battery in Abu Simble $(0.147 \$ / \mathrm{kWh})$ for the electrical production of this system is $123391 \mathrm{kWh} / \mathrm{y}$. LCOE of SPV-wind-diesel-battery in Hurghada $(0.153 \$ / \mathrm{kWh})$ for the electrical production of this system is $121414 \mathrm{kWh} / \mathrm{y}$. LCOE of SPV- wind -dieselbattery in Matrouh $(0.151 \$ / \mathrm{kWh})$ for the electrical production of this system is $121067 \mathrm{kWh} / \mathrm{y}$. LCOE of SPVwind -diesel-battery in Aswan $(0.156 \$ / \mathrm{kWh})$ for the electrical production of this system is $122322 \mathrm{kWh} / \mathrm{y}$. A comparison study for the optimal source for the four regions displays that hybrid SPV-wind in Abu Simble has a higher electrical production value with $123391 \mathrm{kWh} / \mathrm{y}$, while the hybrid SPV-wind in Matrouh has a lower electrical production value of $121067 \mathrm{kWh} / \mathrm{y}$. From the electricity consumptions view, among four hybrid sources with an hourly LCOE presented that the electricity cost of Diesel system with $0.749 \$ / \mathrm{kWh}$ and the electricity cost of SPVwind -diesel-battery with $0.147 \$ / \mathrm{kWh}$ has the high and low value per dollar each hour, respectively in Abu Simble town.

TABLE VII. SYSTEM LCOE ( $\$ / \mathrm{KWH})$ FOR FOUR TOWNS OF DIFFERENT MICROGRIDS.

\begin{tabular}{|l|c|c|c|c|}
\hline & $\begin{array}{l}\text { Abu } \\
\text { Simbel }\end{array}$ & Hurghada & Matrouh & Aswan \\
\hline $\begin{array}{l}\text { SPV-wind- } \\
\text { diesel- } \\
\text { battery }\end{array}$ & 0.147 & 0.153 & 0.151 & 0.156 \\
\hline $\begin{array}{l}\text { wind-diesel- } \\
\text { battery }\end{array}$ & 0.157 & 0.161 & 0.16 & 0.168 \\
\hline $\begin{array}{l}\text { SPV-wind- } \\
\text { battery }\end{array}$ & 0.223 & 0.231 & 0.304 & 0.314 \\
\hline Diesel & 0.749 & 0.749 & 0.749 & 0.749 \\
\hline
\end{tabular}

TABLE VIII. THE LCOE OF SPV- WIND -DIESEL-BATTERY FOR DIFFERENT TOWNS IN EGYPT

\begin{tabular}{|r|r|c|c|c|c|}
\hline & $\begin{array}{r}\text { Abu } \\
\text { Simbel }\end{array}$ & Hurghada & Matrouh & Aswan & $\begin{array}{r}\text { Ref. } \\
{[17]}\end{array}$ \\
\hline $\begin{array}{r}\text { LCOE } \\
(\mathbf{k W h})\end{array}$ & 0.147 & 0.153 & 0.151 & 0.156 & 0.2262 \\
\hline
\end{tabular}

Table VIII shows the comparison of LCOE of different towns in Egypt with the same hybrid source (SPV- wind diesel-battery). The Abu Simble town have the minimum LCOE of $0.147 \$ / \mathrm{kWh}$ and this because of high solar irradiation and wind resources. The highest LCOE with $0.2262 \$ / \mathrm{kWh}$ in Ref [17] because it has low solar irradiation and wind speed resources.

\section{B. RF Calculations}

Renewable fraction (RFs) varies as microgrid architectures for every area taken in the simulations. It could be noticed that from Table IX, that the RFs for every area in the simulations is a notably high value for a diesel price of $\$ 1.3 / 1$. An increase in diesel price favors more addition of SPV panels, resulting in a higher RFs value.

TABLE IX. RFS FOR FOUR TOWNS OF DIFFERENT MICROGRIDS

\begin{tabular}{|c|c|c|c|c|}
\hline & $\begin{array}{c}\text { Abu } \\
\text { Simbel }\end{array}$ & Hurghada & Matrouh & Aswan \\
\hline $\begin{array}{c}\text { SPV-wind- } \\
\text { diesel- } \\
\text { battery }\end{array}$ & 0.99 & 0.99 & 0.99 & 0.99 \\
\hline $\begin{array}{c}\text { Wind-diesel- } \\
\text { battery }\end{array}$ & 0.99 & 0.99 & 0.98 & 0.98 \\
\hline $\begin{array}{c}\text { SPV-wind- } \\
\text { battery }\end{array}$ & 1 & 1 & 1 & 1 \\
\hline Diesel & 0 & 0 & 0 & 0 \\
\hline
\end{tabular}

\section{Carbon emissions.}

The annual $\mathrm{CO} 2$ amount of emissions relate directly to the amounts of fuel consumed by diesel engines per year. Table $\mathrm{X}$ displays a comparison to a total amount of $\mathrm{CO} 2$ emission per year by all configurations for every area with a base case simulation at diesel prices of $1.3 \$ / \mathrm{L}$. In the four hybrid sources, the SPV- wind -battery system has no 
pollution with zero value and the Diesel system has a maximum value of $41125 \mathrm{~kg} / \mathrm{y}$ in the four regions. These gotten results showed that long-term planning for participating in renewable energies is suitable for the four towns.

TABLE X. CO2 EMISSION (KG/YR) FOR FOUR TOWNS OF DIFFERENT MICROGRIDS

\begin{tabular}{|c|c|c|c|c|}
\hline & $\begin{array}{c}\text { Abu } \\
\text { Simbel }\end{array}$ & Hurghada & Matrouh & Aswan \\
\hline $\begin{array}{c}\text { SPV-wind- } \\
\text { diesel-battery }\end{array}$ & 1305 & 1207 & 1636 & 1344 \\
\hline $\begin{array}{c}\text { Wind-diesel- } \\
\text { battery }\end{array}$ & 1771 & 2711 & 2591 & 3033 \\
\hline $\begin{array}{c}\text { SPV-wind- } \\
\text { battery }\end{array}$ & 0 & 0 & 0 & 0 \\
\hline Diesel & 41125 & 41125 & 41125 & 41125 \\
\hline
\end{tabular}

\section{CONCLUSIONS}

In this paper, the feasibility study of hybrid renewable isolated micro-grids in four selected regions of rural areas in Egypt was obtained. Through the investigations for sources availability in every area and the simulations for total isolated micro-grids scenarios, the optimum system architecture, LCOE, and environmental impacts, were quantitatively analyzed. Four isolated micro-grids configurations including standalone diesel-only system, wind/diesel/battery, SPV/wind/battery, and SPV/wind/ diesel/battery, were evaluated by HOMER to get the more economically suitable solution. According to the gotten results for the selected areas in this paper, it can be recommended that: The WIND/SPV/diesel/battery isolated micro-grids are found as optimum planning for diesel price of $\$ 1.3 / 1$, based on the LCOE, and RFs calculations. Also, the best optimum area to install SPV/wind/diesel/battery isolated micro-grids in Egypt is Hurghada. The standalone diesel unit is the highest LCOE $0.749 \$ / \mathrm{kWh}$, and the amount of emission is $41125 \mathrm{~kg} / \mathrm{y}$ of $\mathrm{CO} 2$; this is a large value and will harm the environment. A standalone diesel system is a bad option in all the areas considered, due to the highest LCOE, low RFs, and high pollutions. The overall obtained results isolated micro-grid configurations perform better than the diesel regards to the LCOE for all four simulations, it also displayed a good performance in all areas considering electrical, fuel consumptions and $\mathrm{CO} 2$ reduction. Because of the high capital cost of implementing isolated microgrids and tariff concession require to be established in Egypt to boost investments in isolated micro-grids, to enhance their contributions to the total energy mix, alleviate poverty and rural electrification problems and promote $\mathrm{CO} 2$ emission reduction on the environment.

\section{REFERENCES}

[1] Mohsin, Muhammad, et al. "Integrated effect of energy consumption, economic development, and population growth on $\mathrm{CO} 2$ based environmental degradation: a case of transport sector." Environmental Science and Pollution Research 26.32 (2019): pp.32824-32835.

[2] Almeshqab, Fatema, and Taha Selim Ustun. "Lessons learned from rural electrification initiatives in developing countries: Insights for technical, social, financial and public policy aspects." Renewable and Sustainable Energy Reviews 102 (2019): pp.35-53.

[3] Kasaeian, Alibakhsh, et al. "Optimal design and technical analysis of a grid-connected hybrid photovoltaic/diesel/biogas under different economic conditions: A case study." Energy Conversion and Management 198 (2019).

[4] Tu, Gobinath P. Rajarathnam, and Anthony M. Vassallo. "Optimization of a stand-alone photovoltaicwind-diesel-battery system with multi-layered demand scheduling." Renewable energy 131 (2019): pp.333347.

[5] Haidar, Ahmed, Adila Fakhar, and Kashem Muttaqi. "An effective power dispatch strategy for clustered micro-grids while implementing optimal energy management and power-sharing control using power line communication." IEEE Transactions on Industry Applications (2020).

[6] Das, Promila, Sandip Chanda, and A. De. "Artificial Intelligence-Based Economic Control of Micro-grids: A Review of Application of IoT." Computational Advancement in Communication Circuits and Systems. Springer, Singapore, 2020. pp.145-155.

[7] N'guessan, S. Attemene, et al. "Optimal sizing of a wind, fuel cell, electrolyzer, battery, and supercapacitor system for off-grid applications." International Journal of Hydrogen Energy 45.8 (2020): pp.5512-5525.

[8] Samsatli, Sheila, Iain Staffell, and Nouri J. Samsatli. "Optimal design and operation of integrated windhydrogen-electricity networks for decarbonizing the domestic transport sector in Great Britain." international journal of hydrogen energy 41.1 (2016): pp.447-475.

[9] Bakhtiari, Hamed, and Ramezan Ali Naghizadeh. "Multi-criteria optimal sizing of hybrid renewable energy systems including wind, photovoltaic, battery, and hydrogen storage with $\varepsilon$-constraint method." IET renewable power generation 12.8 (2018): pp. 883-892.

[10] Ferrari, Lorenzo, et al. "Influence of actual component characteristics on the optimal energy mix of a photovoltaic-wind-diesel hybrid system for a remote off-grid application." Journal of cleaner production 178 (2018): pp.206-219.

[11] Yilmaz, Saban, and Furkan Dincer. "Optimal design of hybrid PV-Diesel-Battery systems for isolated lands: A case study for Kilis, Turkey." Renewable and Sustainable Energy Reviews 77 (2017): pp.344-352.

[12] Mandal, Soumya, Barun K. Das, and Najmul Hoque. "Optimum sizing of a stand-alone hybrid energy system for rural electrification in Bangladesh." Journal of Cleaner Production 200 (2018): pp.12-27.

[13] Dawoud, Samir M. "Developing different hybrid renewable sources of residential loads as a reliable method to realize energy sustainability." Alexandria Engineering Journal 60.2(2020): pp.2435-2445.

[14] Rad, Mohammad Amin Vaziri, et al. "Technoeconomic assessment of a hybrid system for energy supply in the affected areas by natural disasters: a case 
Vol. 41, No.2. July 2022

study." Energy Conversion and Management 221 (2020): 113170.

[15] TSAI, Huan-Liang, et al. Development of generalized photovoltaic model using MATLAB/SIMULINK. In: Proceedings of the world congress on engineering and computer science (2008): pp. 1-6.

[16] Vendoti, Suresh, M. Muralidhar, and R. Kiranmayi. "Techno-economic analysis of off-grid solar/wind/biogas/biomass/fuel cell/battery system for electrification in a cluster of villages by HOMER software." Environment, Development, and Sustainability (2020): pp.1-22.

[17] Ibrahim, Mostafa M., et al. "Performance analysis of a stand-alone hybrid energy system for desalination unit in Egypt." Energy Conversion and Management 215 (2020): 112941. 